\title{
Notes and News
}

\section{The Blending of Cultures.}

CULTURE contact is a problem which engages the minds of administrators and educators in all those countries where a primitive civilization has to adapt itself to Western conditions. An interesting contribution to the questions arising out of this situation is furnished by Mr. F. E. Williams, a Government Anthropologist in Papua Territory. ${ }^{\mathrm{I}}$

As the title of his paper suggests, Mr. Williams's ideal in education is a blending of the old and the new. He thinks Europeanization is a mistake, and the exponents of such a policy have been responsible for some of the worst errors in native education. 'The complacent conviction that our own culture is at all points superior to the native's, and the idea that it may be transplanted by simple straightforward conversion has led us to force European traditions and learning upon him without regard to their fitness or usefulness.' This method entails the loss of much that is admirable in native culture which is peculiarly fitted, by generations of selection and confirmation, to the native genius, and all this should be retained and strengthened as far as is compatible with modern requirements. Instead of forcing the native into a position in which he becomes a mere imitator, definitely accepting a status of inferiority, ' he should keep enough of the past to ensure a measure of cultural independence wherewith to sustain his pride and his corporate self-respect'. With this end in view, the main tasks of education are, according to Mr. Williams, to maintain and encourage all that is good in the old culture, to remove from it its evil elements, and to make positive contributions from our own culture. Here, naturally, several questions arise, e.g. can a culture be interfered with, and that by a person who lives in a totally different culture? Which are the good elements that should be retained and which are the evil ones that should be eliminated? Culture is more than a complicated mechanism in which the loss of one, however small, part destroys the whole machine; Mr. Williams is right in saying that culture is an organism. Now the characteristic feature of an organism is that it is constantly changing - it grows and develops and adapts itself to new needs and conditions. A tree is different in winter and in summer, in youth and in old age, on sand and on loamy soil, yet it is always the same tree. No culture remains unchanged, it is in a constant process of transformation. All

I F. E. Williams, "The Blending of Cultures, an Essay on the Aims of Native Education.' Anthropological Report, No. 6, Port Moresby, I935. 
cultures have in the course of their lives borrowed from others, have developed new elements and have thrown off elements which had become useless. We see to-day African cultures assimilating European features without necessarily losing their own identity. What the outcome will be, whether the new will ultimately crush the old, we do not yet know, but that a blending of cultures is possible and out of combining elements a new and stronger unit may arise, can hardly be doubted. What are all European cultures but blendings?

But if we European educators are bold enough to direct the process according to our own wisdom-which are the elements to be retained or rejected? This is, according to Mr. Williams, to be decided by the anthropologist. He is adopting a cause and it is necessary for him that he should descend 'from the serene heights of objectivity onto the bumpy and controversial ground of values. ... He must indeed form his own judgements of what is right or wrong, good or bad, if he wishes to bear any active part in the application of his science to practical problems'. 'This is no doubt true, but the justification for such an attitude of arbiter morum must be based on a thorough and prolonged observation of the culture and its actual working, not only by the expert anthropologist, but also the practical man, in the first instance the administrator and the missionary, and before important changes are put into effect experienced natives must also be heard. Many ' evil' customs, such as head-hunting, disappear automatically after the establishment of European rule; others, like sorcery, cannot be eliminated by law but only by patient education, and on the whole the way of teaching the good will be more successful than trying to suppress the bad-the less we interfere the better. This is particularly true of the social system and its sanctions-it is the life centre of native society; even where it does not wholly correspond to what we think it ought to be, we should respect it and treat it with reverence.

Among the new elements which the European should contribute, the author mentions only three: a reformed horticulture, scholastic education and in particular the teaching of the English language, and Christianity. He is emphatic in stating that "English per se is the most valuable gift we can bestow upon the native'. It should be regarded as the principal aim of scholastic education in the lower grades, and Mr. Williams thinks that the teaching of English can be done "without impairing their knowledge of their own language'. 'This may be questioned. If the vernacular is not used in education and is consequently not cultivated, it sinks to the status of a second-rate cultural element and the educated class will soon begin to neglect and even despise it. From Mr. Williams's standpoint language is a negligible part of a people's heritage, which should have no place in the new dispensation and can be ignored by the educator without harm being done to the native or his culture. It may be convenient to disregard native language, 
it may simplify matters for the European, but how can native culture be developed if it is deprived of its most important means of expression?

Christianity, on the other hand, 'is for the present and the long future the best available kind of spiritual diet we can offer to the primitive peoples'. Its ethical teaching, intellectual content, and emotional values are to be appreciated as the best educational means in giving the native new lifevalues. The reproaches sometimes brought against Christianized natives Mr. Williams dismisses as sheer prejudice. 'The faults attributed to mission training are rather the results of sophistication by intercourse with Europeans and the opportunities and temptations which it offers.'

\section{Migrant Labour in Southern Africa.}

The problems that arise out of the dependence of the large centres of employment in Southern Africa on a shifting labour force drawn from native areas many thousand miles distant have been discussed in the last few months from a number of different points of view. The Report of a Nyasaland Commission appointed in June 1935 to study the effects of mass emigration on labour from that territory is introduced in terms such as are rarely found in an official publication. 'Something must be done at once', the Commission urges, "to remedy a state of affairs which, viewed from any standpoint, constitutes a flagrant breach of the ideal of trusteeship of native races.' Recruiting for employment abroad was not permitted in Nyasaland from I 909 to 1934 , and individual emigration was in theory controlled by a pass system intended to restrict the numbers leaving the territory. In fact the percentage of adult males estimated to be absent from their homes is over so in some districts of the Northern Province and in Mzimba attains 65. From 25 to 30 per cent. of these never return-and native language calls them by a special name, machona, 'the lost ones'. The absence of alternative sources of money revenue has created a situation here as serious as anywhere in Africa. In the north of Nyasaland native production is almost nonexistent, and in some areas there is insufficient land, or the soil is too poor, for its development to be possible. Local employers cannot offer wages which would compete with those earned in the territories farther south, and many prefer to employ immigrants from Portuguese East Africa on the ground that the labourer with no local ties works better.

The strongest pressure to emigrate comes from the hut and poll tax, which is levied on plural wives and adult unmarried women as well as on males. But the change in the material standard of native life is also important. A man is expected to provide his dependents with cloth, blankets, and other imported goods, to pay school fees for his children, and the bride-price is now normally paid in cash. The love of travel for its own sake accounts for some emigration of young men, but this does not in itself lead to the prolonged or permanent absence the social results of which are so disastrous. 